\title{
Employability of Senior High School Graduates under TECHVOC Track with National Certification in Graphics and Animation from TESDA
}

\section{Love Cabrera Asis}

De La Salle University Manila, De La Salle College of Saint Benilde, Lycem of the Philippines University, Manila, Philippines.

\begin{abstract}
How to cite this paper: Love Cabrera Asis. (2020). Employability of Senior High School Graduates under TECHVOC Track with National Certification in Graphics and Animation from TESDA. The Educational Review, USA, 4(12), 219-224.

DOI: 10.26855/er.2020.12.002
\end{abstract}

Received: October 22, 2020

Accepted: November 26, 2020

Published: December 22, 2020

Corresponding author: Love Cabrera Asis, De La Salle University Manila, De La Salle College of Saint Benilde, Lycem of the Philippines University, Manila, Philippines.

Email: love.asis@gmail.com

\begin{abstract}
In 2012, then Philippine President Benigno Aquino III, sign into law the Republic Act 10533 or The Enhanced Basic Education Act of 2013 or most commonly known as K-12. The new curriculum was implemented in the school year 2012-13 starting from public schools and later followed by private schools. The law requires three government agencies such as DepED, CHED and TESDA to collaborate in formulating, harmonizing and avoid redundant subject in the enhanced basic education curriculum. The K-12 curriculum is composed of kinder to grade 6 as primary education, grade 7 to 10 as junior high school and the additional 2 years, grades 11 \& amp; 12 as senior high school. Through different tracks and strands, the added two years as senior high school ensures the college readiness of the graduates and at the same time the employability in case they decided not to pursue college. Among the track is TECHVOC that requires certificate of competency and or National certification of their chosen strand through TESDA programs. However, after years of implementation it is still questionable that the first wave of graduates is employable after senior high school. The objective of this descriptive research is to give better understanding and avoid misconceptions about the employability of senior high school graduates in TECHVOC specifically ICT in graphics arts and animation under the competency by TESDA accredited training and assessment program. The researcher also aims to give in-depth information about the new curriculum, its supporting government agencies and private sectors, and expectations from graduates of senior high.
\end{abstract}

Keywords

Employability, K-12, Graduates, certification

\section{Introduction}

$\mathrm{K}-12$ or $\mathrm{K}$ through 12, K-twelve or $\mathrm{K}$ to twelve is an education system originated in the United States that indicates the number of years of publicly supported education prior to college. It was named after Akron, Ohio where the system first conceived as law which attempts the unification of curriculums and local education funding. Thus, the Akron School Law of 1847 paved the changes in the education system from local to international standard. Since its inception 
as law, K-12 has gone through several waves of debates and reform to standardize and uptick the quality of education. Just as when Philippine education system adopted this into law as Republic Act 1033 or the Enhanced Basic Education 2013 signed by then Philippine President Benigno Aquino III. It was implemented in the school year 2012-13, which started in public schools and later followed by private schools. As of writing there were two batches of Senior High school graduates from school year 2017-18 and 2018-19, and so the effect of the program remains in question as to whether the objective was achieved. Particularly the knowledge and skills of Senior High graduate in technical-vocational strands wherein graduates are expected to be employable.

The first part of this paper states the background of K-12 education as it translates into Philippine education system which by itself influenced by foreign education. The succeeding part explains the K-12 in terms of local implementation, objectives, expectations as well as the government agencies involved. The last part of this paper concludes with an explanation as to the notions on the employability of senior high graduates specifically in Arts, Animation and Graphics Arts for Technical-Vocational-Livelihood track.

\section{Background}

K-12 starts with 1 year preparatory schooling or kindergarten, then twelve years of basic education. The twelve years pertains to 6 years of primary school, 4 years of junior and 2 years of senior high school. The added 2 years of high school prepares students for tertiary education, skills development, employability and entrepreneurship.

K-12 was originated in the United States of America. Public schooling was introduced in the 17th century which focuses on teaching family virtues, religion and community works [Board and Board, 2019]. In the late 18th century, public schooling was first envisioned as free education for families that could not afford. During this period, schooling became compulsory for ages 8-14 years old as main responsibility for teaching academics. Schools are often operated exclusively, offering dedicated curriculums. However, it was in the State of Ohio that the attempt to unify the curriculum was first conceived and put into law in 1849. The objective of this legislature is to unify the school systems in terms of curriculum, operations, government funding among others [Ohiohistorycentral.org, 2019]. In the year 1930s, 50 states had passed a law that is making education compulsory and were later signed by President Lyndon B Johnson making Elementary and Secondary Education Act (ESEA) into law. Since the implementation of this law, several waves of reform has been debated and developed to uptick the education system not only locally but was also adopted by other countries such as Canada, Australia, Ecuador, and Middle Eastern countries such as Egypt, India, Iran, Turkey, as well as in Southeast Asian Countries.

Education in Southeast Asian countries on private education expenditures are increasing due to demand for high education with market coming from middle class. The demand is driven by; shrinking household which was used to an extended family, rapid urbanization that led to increasing demand for better quality education and eventually higher income, affordability due to robust economic performance and steady rise on average income per household, low capacity against demand driven by overburdened public education system, value of English proficiency which became essential requirement in getting a job which also lead to the last driver, the desire for international education for better opportunity in the local and international market (Education in Southeast Asia Opportunities for investors and operators, 2016). The aforementioned drivers seek standard education recognized internationally. Philippines were one of the last among Asian countries and one of the 3 last countries around the world that had a 10 years education program, Angola and Djibuti as the other two.

\section{Philippine Education Systems}

International influence for formal education in the Philippines has been in existence since the colonial period, way before 1500s. During this time, the country basic economy is through agriculture, livestock, fishing, mining, lumbering and ship building, weaving and trading. Education system is preexisting through vocational training, parental guidance and tribal tutors while teaching is commonly done through oral and baybayin or writing. Academic and vocational educations were given according to needs. Given economic status, parents teach their children to do hunting, fishing, mining, ship builders and to be a warrior particularly for their son by their father. Daughters on the other hand were taught by their mother to do cooking, gardening, household chores and crafts to prepare them from parental responsibilities. Academic teaching through schooling or Bothoan is done by older man in charge in reading, writing, arithmetic and use of weapons (Teacher.ph, 2019). Culture during this time is basically Malayan structure and form with written and language for communication and literary expressions. Teaching by Babaylan and Katalonan are more of beliefs and traditions. Although literacy rate is high, this makes them susceptible to foreign influences.

During the Spanish period in 1520s, religious setup of education such as parochial school and books for education 
was introduced. Schools and type of education are categorized according to social class, gender and private or public owned schools. Private schools are owned by individuals and founded by non-Spaniards which was brought missionaries, while public schools are government or owned by Spaniards which offers free education. Christianity was the principal goal during this period making religion as compulsory in primary schools and universities. Gender separation for school was implemented which basically teaches practical skills, reading, writing and arithmetic and vocational course. High school, now equivalent to tertiary school teaches psychology, mathematics, history, geography and Latin was introduced in $17^{\text {th }}$ century by missionaries.

The most important and notable contribution came during the American occupation nearly in 1900s, service men or armies are teaching the through select books and English language was introduced. Filipinos became pensionados for United State government finance education that focuses on training the Filipino for self-governance by removing the compulsory religion subjects, recruiting teachers, become a leader and to foster love for country among the youth. However, the increasing number of enrollees results to a shortage on teachers. Education system was reduced from 7 years of elementary to 6 years and 4 years of high school that is equivalent to college. High school came into being only in the early years of 1900s. School emerges roughly 10 years later due to growing number of enrollees, economic depression, technological development and medium to large business demands for workers. High school curriculum then focuses on practical skills to prepare them for work (Dalmacio, 1980).

During Japanese colonization, schools and churches were used to propagate Japanese language. A Japanese Military Administration's Order No 2 of February 1942 was released with six basic points in education: propagating Filipino culture, dissemination of the principles of the Greater East Asia Co-Prosperity Sphere, spiritual rejuvenation of the Filipinos, teaching and propagating of Niponggo, diffusion of vocational and elementary education, and promotion of love of labor (DepEd, 2019).

By year 1945 to 2011 was using a compulsory Kindergarten and pre-schooling, six years of primary schooling or elementary and 4 years of secondary or high school, now pertains to junior high. Being grades 1-3 as primary with student age range from 6 to 9 years old, grades 4-6 as intermediate for age range 9 to 12 years old, high school at first year is freshman, second year as sophomore, third as junior and $4^{\text {th }}$ year as senior high school for the age range of 12-16 years old. The ten years of primary and secondary schooling can be followed by 1-2 years vocational or certification course or 4-5 years college degree or tertiary schooling for career base courses. The 10 years of education are then called undergraduate or graduate school. Additional 3-4 years of education for post graduate studies or masteral degree and 5-6 years for doctoral.

Education is provided through public or private schooling, academy and colleges, universities, technical and vocational. In 1991, Congressional Commission on Education (EDCOM) was split into 3 divisions the department through Republic Acts 7722 and 7796 in 1994 or the trifocalization of education system. CHED or Commission on Higher Education supervise the tertiary degree programs, while TESDA or Technical- Vocational Education and Skills Development Authority handles the non-degree technical-vocational programs. DECS or Department of Education, Culture and Sports remains accountable for primary and secondary programs. The department was later changed to DepEd or Department of education under the Republic Act 9155, Governance of Basic Education Act in 2011.

In 2010, then Senator Benigno Aquino III has already expressed the desire to develop the Philippine education system by increasing the number of compulsory education from 10 years to 13 years following the K-6-4-2 or K-12 basic education system and standards. This will make Kindergarten one year as compulsory under the Kindergarten Education Act of 2012, while 6 years of primary, and 4 years of junior high school and 2 years of senior high school was made official through the virtue of Enhanced Basic Education Program Act or Republic Act 10533 of 2012. However, DepEd has been implementing the K-12 since school year 2011-2012 but only enacted as law in 2013 (CHED K to 12 Transition Program, 2019).

\section{The Enhanced Basic Education Act of 2012}

Stated on Department of Education website and government Official Gazette website, the K-12 Basic Education program will provide sufficient mastery of concepts and skills, develop lifelong learners, and prepares graduates for tertiary education, middle-level skills development, employment and entrepreneurship (Official Gazette of the Republic of the Philippines, 2019). This system made it compulsory for kindergarten education wherein children at the age of 5 years old are given resources to slowly adjust to formal education and two years academic or vocational courses in preparation to tertiary school and or employment to graduates of senior high school. Grades 1 to 12 still remains as primary and secondary education but curriculum was developed in a contextualization and enhancement with in depth knowledge, skills, values, and attitude through spiral progression, proficiency in mother tongue and languages.

Senior high school or specialized secondary education is the added 2 years of; Academic, Technic- 
al-Vocational-Livelihood and Sports, Arts and Design track based on aptitude, interest, and school capacity. Each track has strands to choose from. Academic track includes; Business, Accountancy, Management (BAM), Humanities, Education, Social Science (HESS), and Science, Technology, Engineering, Mathematics (STEM).

The core curriculum of senior high school includes: Oral Communication, Reading and Writing, Komunikasyon at Pananaliksik sa Wika at Kulturang Pilipino, Pagbasa at Pagsusuri ng Iba't-Ibang Teksto Tungo sa Pananaliksik, $21^{\text {st }}$ Century Literature from the Philippines and the World, Contemporary Philippine Arts from the Regions, Media and Information Literacy, General Math, Statistics and Probability, Earth and Life Science, Physical Science, Introduction to the Philosophy of the Human Person, Physical Education and Health, Personal Development, Understanding Culture, Society and Politics, Disaster Readiness and Risk Reduction (Deped.gov.ph, 2019).

Applied Tracks Subjects however includes: English for Academic and Professional Purposes, Practical Research 1 \& 2, Filipino sa Piling Larang, Empowerment Technologies (for the strand), Entrepreneurship, Inquiries, Investigations and Immersions.

Academic track includes: Accountancy, Business and Math (ABM), Human and Social Sciences (HUMSS), STEM, General Academic Strand (GAS), Pre-Baccalaureate Maritime.

Technology and Livelihood Education (TLE) and Technical-Vocational-Livelihood (TVL) tracks offers specialization designed to provide students with job-ready skills. An equivalent number of hours during grades 9-12 and an exploratory subject for 40 hours in grade 7-8. This track requires competency and/or National Certification. There are four strands for this track: Agri-Fishery Arts (animal production, crop, landscaping, food processing and fisheries), Home Economics (business, fashion design chief entrepreneur, beauty and wellness, cooking, tourism and hospitality, and handicrafts), Industrial Arts (plumbing, welding, repair and installation, automotive, electronics, carpentry and constructions) and Information and Communication Technology or ICT (software, hardware installation, computer programming and servicing contact center-services and graphics). Thus, focuses on skill development in terms of communication, critical thinking, body coordination, tool savvy, trouble shooting and safety (Karl Nicole, 2019).

\section{Status of Implementation}

The implementation of K-12 in the Philippines during the school year 2012-13 has made a huge impact in the education system of the country. It was first implemented in public schools then later followed by private schools. Entry grade 1 and 7 are the first to undergo the transition stage. The implementation requires the collaboration of 3 government agencies included in the trifocalization: DepEd, CHED and TESDA, their core responsibility remains to primary education for DepEd, CHED for tertiary and TESDA for vocational courses. The adjustment period for the implementation is not limited to primary school. Most of the tertiary general education subjects are included in the Core Curriculum for Senior High school. This left Tertiary education to adjust their curriculum as well to a more career related subjects. TESDA on the other hand widens its training and certification scope from high school graduates to ongoing senior high school curriculum.

As one of the objective of implementing additional senior high school of two years aims to prepare the graduates to college, future employability and or entrepreneurial. However, DepEd cannot guarantee immediate employment (Newsinfo.inquirer.net, 2019). This resulted to question the credibility of implementing senior high school (SHS). Instead, DepEd ensure that this will create opportunities for cultivating the abilities of the students by fostering partnerships with companies through technical vocation and eligibility to apply for Certificate of Competency (COC) and National Certification (NC) issued by TESDA.

\section{Discussion}

The transition period upon the implementation of SHS has gone through two batches of graduates already under school year 2017-18 and 2018-19. Before the end of junior year, students were asked to take an evaluation exam to help them determine what track they are going to take during their senior high school. This exam though is just a guide but not compulsory.

As a professor for tertiary and certified trainer for TESDA; teaching animation, multimedia and fine arts and design, I took the freedom in asking my student as to their experiences in taking the SHS being they are among the 2 batches to undergone it. The primary purpose of this is to get to know the student, evaluate current skills and knowledge by introducing themselves in class and state prior education background. This though led to sharing their perception, experiences and opinion in the implementation of the senior high school. By asking the class to raise their hand if they feel they have experienced the same as their classmate which resulted the tables below. 


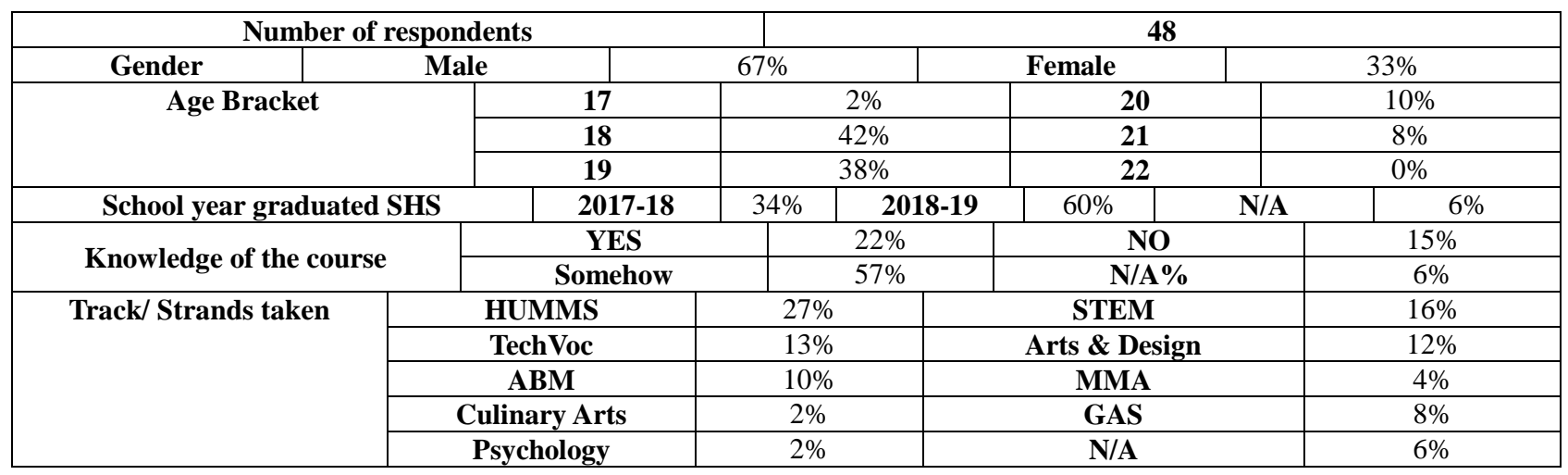

\begin{tabular}{|c|c|c|c|c|}
\hline & Yes & No & Somehow/ Maybe & N/A \\
\hline Expectation met according to track description & $58 \%$ & $17 \%$ & $19 \%$ & $6 \%$ \\
\hline Track/strands taken is related to tertiary course & $22 \%$ & $32 \%$ & $40 \%$ & $6 \%$ \\
\hline Will take the same track/ strand & $46 \%$ & $42 \%$ & $6 \%$ & $6 \%$ \\
\hline Believe that there is an advantage in SHS & $23 \%$ & $15 \%$ & $56 \%$ & $6 \%$ \\
\hline Expect to be employable after SHS & $35 \%$ & $50 \%$ & $9 \%$ & $6 \%$ \\
\hline Will attempt to apply for the job & $56 \%$ & $31 \%$ & $7 \%$ & $6 \%$ \\
\hline Believe that Tertiary schooling is important & $83 \%$ & $6 \%$ & $5 \%$ & $6 \%$ \\
\hline
\end{tabular}

In summary, majority of them took HUMMS for SHS strand since as per orientation with them it will help them hone their skills in preparation for Multimedia arts which is their current course they taking up. HUMMS strands focuses on the study of human behavior and societal changes, and analysis of arts, culture, literature and politics. It involves political science, anthropology, linguistics, psychology and communication. The subject includes Creative Writing, Introduction to World Religions and Beliefs System, Creative nonfication, Trends, Networks and Critical Thinking in the $21^{\text {st }}$ Century Culture, Philippine Politics and Governance, Community Engagement, Solidarity and Citizenship, Disciplines and Ideas in Social Sciences, and work immersions on research, career advocacy and culminating activities. Although according to them their orientation on the strand they took is misleading and they felt that majority of schools is still not ready yet with the implementation they will take the same strand if given the chance to change. While they think it is not related to their course they are currently taking knowledge, skills and attitude was developed and taking SHS will benefit the education of next generation if properly implemented. In addition, these students still believe that it is important to attend tertiary school because they are not confident yet with the skills needed for their chosen career. The reason for this is because not all of them took the track related to their chosen tertiary course and that they are still undecided on what course to take. SHS also brought them to realization on what course they will take for college. Even though they see the importance of education particularly in college, they will still try their luck and skills in finding a job after SHS, Not only to prove they are ready to work but they sees this as venue to earn money for personal support.

\section{Recommendation}

The employability of SHS after graduation remains uncertain. However, this is not the primary goal for the transition to K-12 education system but rather prepares the students for their chosen tertiary course and an option to continue their education. In case that the student graduated SHS and they will not be able to continue their education for degree courses, the two years SHS will help them find a job according to their current skills, knowledge and attitude they gained from the track they have taken in their SHS.

As the result to the discussion with my students in class are agreeable on my part in terms of the importance of finishing tertiary education. This situation will remain for many Filipino since everyone wishes to improve their life. However, creative industry is not after the number of diplomas or certificates you received during schooling but rather the portfolio showcasing the skills, output and meeting the deadline is more imperative. During my conversation with some colleague from creative industry as to whether they are open to hire SHS graduates, majority of them will accept on condition that they have to go through training stage for hiring them full time/ regular employee. This on job training 
benefits not only the company but also the employee who wish to stay long term in the company.

TESDA program with Certificate of Competency and National Certification offers arts related courses such as 2D animation, 3D animation, Game Art Development, Visual Arts, Digital Arts Technology and Illustration. The certification granted by TESDA through standardized assessment and training is internationally and nationally recognized. Filipinos that are planning to work abroad are applying for the training and certification programs. Graduates of senior high school that took the TechVoc may take the certification exam that can help them find a job.

However, not all the aforementioned training courses offered by TESDA are qualified for the TeachVoc but 2D animation and visual graphics. Interested graduates though are free to take the assessment exam for their certification on programs not included for SHS.

\section{References}

Board, T. and Board, T. (2019). 11 Facts About the History of Education in America. [online] American Board Blog. Available at: https://www.americanboard.org/blog/11-facts-about-the-history-of-education-in-america/ [Accessed 14 Sep. 2019 ].

CHED K to 12 Transition Program. (2019). A Historical Perspective. [online] Available at: https://chedk12.wordpress. com/a-historical-perspective/ [Accessed 10 Sep. 2019].

Dalmacio, Martin. (1980). A Century of Education in the Philippines, 1861-1961. Manila: Philippine Historical Association. pp. 115-221.

DepEd. (2019). HISTORICAL PERSPECTIVE OF THE PHILIPPINE EDUCATIONAL SYSTEM. [online] Available at: https://www.deped.gov.ph/about-deped/history/ [Accessed 5 Sep. 2019].

Deped.gov.ph. (2019). Senior High School Core Curriculum Subjects I Department of Education. [online] Available at: https://www.deped.gov.ph/k-to-12/about/k-to-12-basic-education-curriculum/senior-high-school-core-curriculum-subjects/ [Accessed 15 Sep. 2019].

Dustin, H. (2019). Federal role in education has a long history. www.theconversation.com. Retrieved 2019-02-04. [online] The Conversation. Available at: http://theconversation.com/federal-role-in-education-has-a-long-history-74807 [Accessed 14 Sep. 2019].

Education in Southeast Asia Opportunities for investors and operators. (2016). [ebook] Ernst \& Young LLP. Available at: https://www.parthenon.ey.com/po/en/home [Accessed 14 July. 2019].

Karl Nicole, N. (2019). Here’s Everything You Should Know About the TVL Track. [Blog] all about senior high. Available at: https://blog.edukasyon.ph/senior-high/heres-everything-you-should-know-about-the-TVL-track/ [Accessed 15 July. 2019].

Newsinfo.inquirer.net. (2019). What went before: The K-12 program. [online] Available at: https://newsinfo.inquirer.net/ 980733/what-went-before-the-k-12-program [Accessed 15 Sep. 2019].

Official Gazette of the Republic of the Philippines. (2019). The K to 12 Basic Education Program | GOVPH. [Online] Available at: https://www.officialgazette.gov.ph/k-12/\#a-section-3 [Accessed 15 Sep. 2019].

Ohiohistorycentral.org. (2019). Akron School Law_Ohio History Central. [online] Available at: https://ohiohistorycentral.org/ w/Akron_School_Law [Accessed 14 Sep. 2019].

Post, G. (2019). A History of the System of Education in the Philippines. [online] TeacherPH. Available at: https://www.teacherph.com/history-system-education-philippines/ [Accessed 15 Aug. 2019]. 